\title{
Article
}

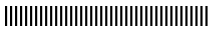

\section{A Multiwire Proportional Counter System for the Measurement of Alpha and Beta Particle Surface Emission Rates}

\author{
Yasushi Sato*, Takahiro Yamada*,**, Mikio Matsumoto**, Shinichi Yamamoto**, \\ Yasuhiro UNNO* and Akira YUNOKI* \\ *National Institute of Advanced Industrial Science and Technology \\ Central 2, 1-1-1 Umezono, Tsukuba-shi, Ibaraki Pref. 305-8568, Japan \\ **Japan Radioisotope Association \\ 2-28-45 Hon-komagome, Bunkyo-ku, Tokyo 113-8941, Japan
}

Received November 28, 2011

\begin{abstract}
A windowless multiwire proportional counter was installed at AIST to determine alpha and beta particle emission rates for $100 \mathrm{~mm} \times 150 \mathrm{~mm}$ surface sources. The detector system was characterized and its parameters were optimized. In addition, the uncertainties in the alpha and beta particle emission rates measurements were estimated.
\end{abstract}

Key Words : alpha particle, beta particle, surface emission rate, multiwire proportional counter, americium-241, chlorine-36

\section{Introduction}

Surface contamination monitors are widely used in radiation protection. They are calibrated by surface sources with surface emission rates whose characteristics are specified by ISO $8769^{1}$. The recommended dimensions of reference sources are $100 \mathrm{~mm} \times 100 \mathrm{~mm}$ and $100 \mathrm{~mm} \times 150 \mathrm{~mm}$. Reference sources are calibrated at national or international metrology institutes or laboratories that have been accredited to ISO17025 ${ }^{1-5)}$. The National Institute of Advanced Industrial Science and Technology (AIST) maintains and supplies primary standards in Japan. Surface emission rates on surface sources with dimensions of $100 \mathrm{~mm} \times$ $100 \mathrm{~mm}$ are calibrated using a multiwire proportional counter (MWPC) in AIST.

A new MWPC has been installed at AIST to extend the dimension of surface sources that are used for calibration of $100 \mathrm{~mm} \times 150 \mathrm{~mm}$ surface sources.

This paper describes the characteristics of this MWPC and presents measurement results for surface sources with dimensions of $100 \mathrm{~mm}$ $\times 150 \mathrm{~mm}$.

\section{Measurement system}

Figure 1 shows a block diagram of the MWPC system. The MWPC is windowless and gas flow type. The sensitive volume is $270 \times$ $320 \times 20 \mathrm{~mm}$. Figure 2 shows design of the MWPC. The counting circuit consists of a preamplifier, a high-voltage supply, a multichannel analyzer (MCA), and NIM modules (an amplifier, a delay and gate generator, a delay generator, and counters). Counting data are transferred to a computer via a general purpose interface bus. The gas is $90 \%$ argon and $10 \%$ methane. It is at atmospheric pressure and its 




Fig. 1 Block diagram of multiwire proportional counter system.



Fig. 2 Design of the MWPC (courtesy of REPIC CORPORATION).

flow rate is adjusted using a regulator and a needle valve.

\section{Characteristics of measurement system}

\section{$3 \cdot 1$ Threshold}

Detection threshold for alpha particles was set above the electrical noise and for beta particle was set by using the following procedure.

First, a spectrum of characteristic X-rays emitted from ${ }^{55} \mathrm{Fe}$ was measured with an MCA. The threshold was then set as near as possible to $0.5 \mathrm{keV}$ photon energy referring to peak (5.9 $\mathrm{keV}$ ) of the characteristic X-rays. Figure 3 shows the characteristic X-ray spectrum and the beta particle detection threshold.

\section{$3 \cdot 2$ Plateau characteristics}

Figure 4 shows plateau curves for ${ }^{241} \mathrm{Am}$ and ${ }^{36} \mathrm{Cl}$. The operating voltage for ${ }^{241} \mathrm{Am}$ was se-

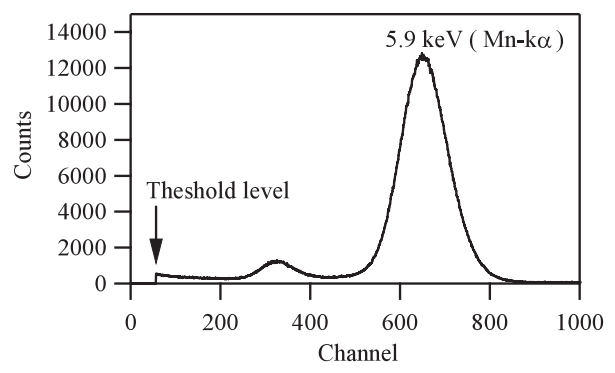

Fig. $3{ }^{55} \mathrm{Fe}$ energy spectrum. The arrow indicates the beta particle detection threshold.
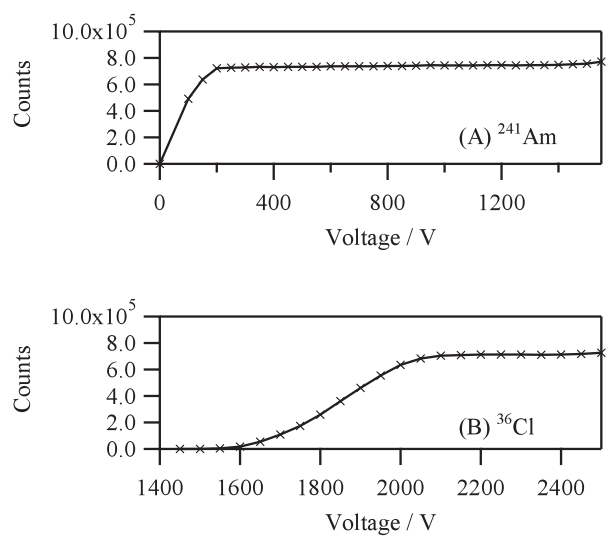

Fig. 4 Alpha and beta plateau curves measured with ${ }^{241} \mathrm{Am}(\mathrm{A})$ and ${ }^{36} \mathrm{Cl}(\mathrm{B})$.

lected to be in the plateau region considering the level of pedestal events. The operating voltage for ${ }^{36} \mathrm{Cl}$ was selected to be in the plateau region considering the level of pedestal events and the threshold determined by the energy peak of the characteristic X-rays of ${ }^{55} \mathrm{Fe}$.

\section{$3 \cdot 3$ Dead time}

The non-extended dead time was set to 5.0 $\mu$ s using with the gate and delay generator module. Dead time and background correction were applied to the measured count rate using the following equation :

$$
\rho=\frac{R}{1-R \tau}-b,
$$

where $\rho$ is the corrected count rate, $R$ is the 

of alpha and beta particle surface emission rates

measured count rate, $b$ is the background counting rate, and $\tau$ is the dead time.

\section{Results}

The surface emission rates of ${ }^{241} \mathrm{Am}$ and ${ }^{36} \mathrm{Cl}$ surface sources are measured by the characterized MWPC in AIST. The uncertainties were estimated according to the ISO guide for determining measurement uncertainties ${ }^{6)}$. There are two types of evaluations of standard uncertainty components. Type A evaluations of standard uncertainty components are based on frequency distributions; in other words, type A evaluations are based on statistical analysis of experimental data. Gaussian distribution is usually assumed and uncertainty is derived from experimental standard deviation. In this experiment, duration times, numbers of measurements, mean count rates and experimental standard deviations of mean count rates for ${ }^{241} \mathrm{Am}$ and ${ }^{36} \mathrm{Cl}$ surface sources were $500 \mathrm{~s} \times 10, \quad 1.514 \times 10^{3} \mathrm{~s}^{-1}, 0.5 \mathrm{~s}^{-1}, 500 \mathrm{~s} \times 10$, $1.440 \times 10^{3} \mathrm{~s}^{-1}$ and $0.7 \mathrm{~s}^{-1}$, respectively. Type B evaluations are found from a priori distributions; in other words, type B evaluations are based on all the available information, such as parameters associated with calibration measurement standards, certificated reference materials, reference data from handbooks, previous measurement data, manufacturer's specifications, experience, and general knowledge. The combined uncertainty was calculated by the root sum square of all the standard uncertainty components. The expand uncertainty is obtained by multiplying the combined standard uncertainty by a coverage factor that would provide an interval produced by expand uncertainty corresponding to a particular level of confidence (in this case about 95\%). Table 1 shows a budget sheet for the uncertainties.
Table 1 Budget sheet for uncertainties

\begin{tabular}{|c|c|c|c|c|}
\hline \multirow[t]{3}{*}{ Source of uncertainty } & \multicolumn{4}{|c|}{ Standard uncertainties (\%) } \\
\hline & \multicolumn{2}{|l|}{${ }^{241} \mathrm{Am}$} & \multicolumn{2}{|l|}{${ }^{36} \mathrm{Cl}$} \\
\hline & A & $\mathrm{B}$ & A & B \\
\hline Estimated standard deviation of the mean & 0.03 & & 0.05 & \\
\hline High voltage & & 0.52 & & 0.70 \\
\hline Threshold & & 0.35 & & 0.26 \\
\hline Background & & $<0.01$ & & $<0.01$ \\
\hline Dead time & & 0.05 & & 0.05 \\
\hline Time base & & 0.02 & & 0.02 \\
\hline Combined uncertainty & & .63 & & 0.75 \\
\hline Expanded uncertainty $(\mathrm{k}=2)$ & & 1.3 & & 1.5 \\
\hline
\end{tabular}

Items of estimated standard deviation of the mean, high voltage, threshold and time base are fluctuation factors for $R$ in equation 1 . Standard uncertainties of estimated standard deviation of the mean, high voltage, threshold and time base were estimated by variation of count rate $\rho$ in equation 1 based on estimated standard deviation of the mean of count rates, on the range of plateau region, on the change of a division of the discrimination dial and on the measurement minimal digit of duration time. Items of background and dead time are fluctuation factors for $b$ and $\tau$ in equation 1, respectively. Standard uncertainty of background and dead time were estimated by variation of count rate $\rho$ in equation 1 based on experimental standard deviation of the mean of background and on the change of a division of the dead time dial.

The expanded uncertainties for surface source measurements are below 2.0\%. Alpha and beta particle emission rates of the surface sources used for the estimations are respectively $1.525 \pm 0.020$ and $1.437 \pm 0.022 \mathrm{kcps}$, as determined from MWPC measurements.

\section{Conclusion}

A new MWPC was installed at AIST and its detector characteristics were estimated. This MWPC will be used for measuring alpha and 
beta particle emission rates of surface sources that will be used as standard sources for calibrating contamination monitors and the distinction of carrying out of nuclear wastes. International comparison of particle emission rate measurements will be conducted to provide reliable quantitative information on the comparability of national metrology services.

\section{Acknowledgements}

Authors thank REPIC CORPORATION for permission to use the figure of the MWPC. This study was financially supported in part by the Budget for Nuclear Research of the Ministry of Education, Culture, Sports, Science and Technology based on screening and counseling by the Atomic Energy Commission.

\section{References}

1) ISO8769, Reference sources - Calibration of sur- face contamination monitors - Alpha-, beta- and photon emitters, International Organization for Standardization (2010)

2) Lee, K. B., Lee, J. M. and Park, T. S, Measurement of beta surface emission rate from an extended area ${ }^{36} \mathrm{Cl}$ source using a mutiwire proportional counter, Appl. Radiat. Isot., 63, 99-105(2005)

3) Mostert, J. C., A primary standard for the measurement of alpha and beta particle surface emission rate at the National Metrology Institute of South Africa, Appl. Radiat. Isot., 66, 925928(2008)

4) Wuu, J. L., Yuan, M. C., Su, S. H. and Hwang, W. S., The alpha and beta emitter measurement system in INER, Appl. Radiat. Isot., 56, 261-264 (2002)

5) ISO17025, General requirements for the competence of testing and calibration laboratories, Organization for International Standard (2005)

6) JCGM100:2008, Evaluation of measurement data - Guide to the expression of uncertainty in measurement, Joint Committee for Guides in Metrology (2008)

\title{
要旨
}

\section{$\alpha$ 線及び $\beta$ 線放出率測定のための多線式比例計数管計数装置}

佐藤 泰*, 山田崇裕 ${ }^{* * *}$, 松本幹雄 ${ }^{* *}$, 山元真一 $*^{*}$, 海野泰裕 ${ }^{*}$, 柚木 彰*

\author{
*独立行政法人 産業技術総合研究所 \\ 305-8568 茨城県つくば市梅園 1-1-1 中央第 2 \\ $* *$ 社団法人 日本アイソトープ協会 \\ 113-8941 東京都文京区本駒込 2-28-45
}

表面污染検查装置は，放射線防護のために広く用いられている。これらの表面污染検查装置は， 荷電粒子放出率が付与された面線源により校正される。一方, 産業技術総合研究所は, 計量の国家 標準を担っており，荷電粒子放出率については，多線式比例計数管により面線源の測定を行い，面 線源を仲介標準器として，校正業務を行っている。現在まで, $100 \mathrm{~mm} \times 100 \mathrm{~mm}$ の面線源により, 校正業務を行ってきたが, 今回, 新しい多線式比例計数管を導入し, $100 \mathrm{~mm} \times 150 \mathrm{~mm}$ の面線源 によっても, 校正業務が行えるように準備作業を進めている。この新しい多線式比例計数管につい ての特性評価を行うとともに, 校正の不確かさ評価を行った。今後, この多線式比例計数管を, 表 面污染検查装置の校正等のための面線源に, 荷電粒子放出率を付与するために用いていきたい。 